Theoretical/Conceptual Article

\title{
ETIKA BIMBINGAN DAN KONSELING DALAM PENDEKATAN FILSAFAT ILMU
}

\author{
Alfaiz Faiz * \\ STKIP PGRI Sumatera Barat
}

Ari Dharmayanti

Universitas Pendidikan Ganesha

\section{Nofrita}

Universitas Langlangbuana

\begin{abstract}
ETHICS OF GUIDANCE AND COUNSELING IN PHILOSOPHY OF SCIENCE APPROACH. In philosophy view, ethic was a valueable and evaluation about a good and bad things in the human self. Ethic is also call moral philosophy as a apart of axiology in science philosophy. In every science has an axiology that purpose of utilization for prosperity of a human life. Guidance and counseling is a science full of values, that because of it's a multidicipliner science. This based of four field guidance which of personal, learning, social and career. This field has make a counselor must understand and proficiency with sociology, antrophology, psychology, and eduation science. That will lead a counseling as multidicipliner science has a full of values to covering the process of counseling practice. However the axiology of counseling make little complex to discuss in philosophy foundation, also in psychology, sociology, antrophology and education. In this article will describe and discuss an ethics in counseling as a multidicipliner science in the view point of philosophy, psychology, and education. Also an ethics in counseling profession as applicative science.
\end{abstract}

KEYWORDS: Ethics, Guidance and Counseling, Multidicipliner Science, Philosophy of Science, Psychology.

* Corresponding Author: Program Studi Bimbingan dan Konseling, STKIP PGRI Sumatera Barat, Jl. Gunung Pangilun, Padang, Sumatera Barat 25173, Indonesia; Email: alfaiz@ stkip-pgri-sumbar.ac.id, http://orcid.org/0000-0003-1226-0443

Article History: Received: 10-11-2017; Revised: 20-12-2017; Accepted: 02-1-2018

Permalink: http://ijec.ejournal.id/index.php/counseling/article/view/26

How to cite (APA): Faiz, A., Dharmayanthi, A., \& Nofrita. (2018). Etika bimbingan dan konseling dalam pendekatan filsafat ilmu. Indonesian Journal of Educational Counseling, 2(1), 1-12.

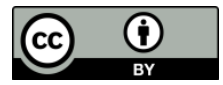

This is an open access article distributed under the terms of the Creative Commons Attribution 4.0 International License, which permits unrestricted use, distribution, and reproduction in any medium, provided the original work is properly cited. (C) 2018, Alfaiz Faiz, Ari Dharmayanthi, Nofrita.

\section{PENDAHULUAN}

Sebagai salah satu disiplin ilmu praktis, bimbingan dan konseling merupakan cabang dari pohon filsafat ilmu manusia yaitu membahas mengenai kondisi jiwa, perilaku manusia dan pikiran manusia, yang dikenal sebagai ilmu psikologi. Dalam perkembanganya ilmu bimbingan dan konseling yang telah memiliki metode tersendiri dalam praktik keilmuannya, seperti halnya pendekatan 
metode eksperimen dan kuantitatif. Implikasi dari perkembangan ilmu bimbingan dan konseling tersebut lebih dipraktikkan pada lembaga pendidikan.

Pendidikan menjadi kawasan keilmuan bimbingan dan konseling tidak terlepas dari perkembangan konseling di Amerika pada abad 20, yaitu William James sebagai bapak bimbingan dan konseling menekankan pelayanan konseling pada pengembangan diri peserta didik dan para mantan veteran militer untuk mengenal keterampilan, bakat dan minat individu agar mampu berkarya dan berkarier di abad 20 setelah terjadinya perang dunia II (Naisaban, 2004).

Konteks pengembangan diri dan pembentukan pribadi merupakan aksiologi dari proses keilmuan bimbingan dan konseling. Nilai dari konseling adalah membantu konseli atau klien sebagaimana mestinya dan seharusnya mereka menjadi (to help the client to be what muste their be) melalui proses membantu dirinya menemukan dirinya, mempersiapkan dirinya dan mengubah dirinya ( to help their self to find it self, to help their self to prepare it self, and to help their self to change it self).

Bimbingan dan konseling sebagai keilmuan yang memiliki nilai dan tujuan bagi kemajuan manusia dalam pendidikan dan proses belajar, memiliki nilai etika dan estetika dalam prinsip dan proses keilmuannya bagi manusia sebagai makhluk yang holistik. Oleh karena itu, pada artikel ini dijelaskan mengenai pertimbangan etika dalam keilmuan bimbingan dan konseling sebagai sebuah ilmu.

\section{KAJIAN LITERATUR}

Immanuel Kant salah satu tokoh filsafat yang berfokus dan menyuarakan tentang moralitas di tengah-tengah euforia pengagungan akal dan rasionalitas pada masa modern. Pandangan Kant seperti tercantum pada kata mutiara yang terdapat di batu nisannya, yaitu: Setinggi-tinggi bintang di langit masih tinggi moralitas di dada manusia menunjukkan kelebihan dan keunggulan manusia dibandingkan dengan makhluk lain adalah pada moralnya (Wilujeng, 2013, p. 79). Kant dan jauh sebelumnya pada masa Yunani kuno, Aristoteles telah fokus pada bagaimana memahami manusia dan alam bekerja dilihat dari segi moral yang dikenal dengan filsafat moral.

Filsafat moral disebut juga dengan etika, hal ini karena etika adalah cabang dari filsafat yang membicarakan tentang nilai baik-buruk. Etika membicarakan pertimbangan tentang tindakan dan sikap baik-buruk, susila tidak susila dalam hubungan antar manusia (Wilujeng, 2013). Etika merupakan pengkajian mengenai sistem nilai (moral) yang berlaku. Berlaku dalam kehidupan sosial, budaya, serta dalam suatu sistem keilmuan yang ada dalam kehidupan manusia. Berbicara baik dan buruk semuanya berkaitan bagaimana manusia menggunakan 
keilmuannya apakah memiliki etika yang benar sesuai dengan tujuan keilmuannya, jadi berkaitan dengan perilaku manusia tersebut baik atau buruk sesuai dengan keilmuan yang mereka miliki (Sya'roni, 2014).

Pendapat Craig (1998, p. 81) menyebut "the term 'ethics is used in three different but related ways, signifying 1) a general pattern or way of life, 2) a set rules of conduct or moral code, 3) inquiry about way of life of rules of conduct". Dalam pandangan tersebut etika digunakan dalam tiga bentuk cara yang berhubungan, yaitu membahas cara hidup manusia dengan pola umum, membentuk aturan atau kode moral, dan penyelidikan tentang cara hidup dari bagaimana aturan diadakan/diselenggarakan. Berarti etika melingkupi kajian aturan dan tatanan nilai baik-buruk yang dibentuk, disusun, dilaksanakan, dan ditujukan oleh suatu sistem sosial maupun sistem keilmuan yang ada. Hubungan etika, filsafat, dan ilmu pengetahuan digambarkan pada diagram di Gambar 1.

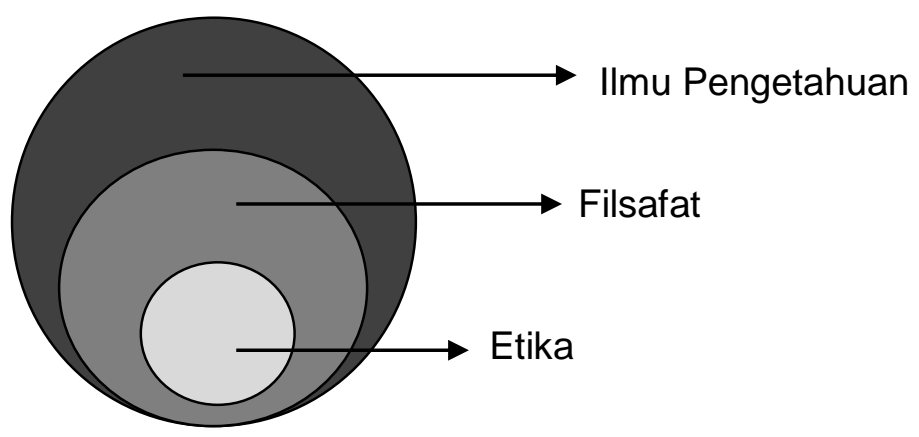

Gambar 1. Hubungan Etika, Filsafat dan Ilmu Pengetahuan

(Burhanudin, 2013)

Dalam perkembangannya, etika dibagi dua, yaitu: 1) Etika Umum, berbicara mengenai kondisi-kondisi dasar bagaimana manusia bertindak secara etis, bagaimana manusia mengambil keputusan etis, teori etika dan prinsip moral dasar yang menjadi pegangan bagi manusia dalam bertindak; 2) Etika Khusus, merupakan penerapan prinsip-prinsip moral dasar dalam bidang kehidupan yang khusus, berwujud bagaimana pengambilan keputusan dan bertindak dalam bidang kehidupan dan kegiatan khusus yang saya lakukan yang didasari oleh cara, teori dan prinsip moral dasar. Etika khusus dibagi menjadi dua, yaitu etika individual: menyangkut kewajiban dan sikap manusia terhadap dirinya sendiri, dan etika sosial: berbicara mengenai kewajiban, sikap dan pola perilaku manusia sebagai umat manusia.

Dalam hal ini dengan dua jenis etika di atas, jelas mendeskripsikan bahwa nilai etika dari suatu sistem sosial atau keilmuan terletak pada penerapannya. IImu mengabdi masyarakat, sehingga menjadi sarana kemajuan. Boleh saja orang mengatakan bahwa ilmu itu mengejar kebenaran, dan kebenaran itu merupakan 
inti etika ilmu, tetapi jangan dilupakan bahwa kebenaran itu ditentukan oleh derajat penerapan praktis dari ilmu oleh manusia sebagai "pemilik ilmu" (the man behind the gun) (Suriasumantri, 2009, p. 234).

Pandangan tersebut tidak berlaku pada masanya Copernicus dan Galileo, hal ini karena para filsuf pada masa itu menemukan pemikiran dan filsafat alam yang terkait antara filsafat dan agama (metafisik). Adapun keterkaitan filsafat dan agama melahirkan filsafat moral. Seperti halnya pandangan Copernicus mengenai bahwa bumi mengelilingi matahari bukan sebaliknya berkaitan dengan konsep agama. Filsafat dan ilmu pada masa itu semata-mata untuk mencari hakikat alam dan kehidupan manusia, tetapi pertanyaan bermunculan, seperti untuk apa ilmu? Ke arah mana ilmu ditujukan? Apa wewenang ilmu? Pertanyaanpertanyaan tersebut memiliki urgensi pada filosof dan ilmuan yang ada pada abad ke 20 karena telah melalui dua perang dunia dan kekhawatiran akan muncul perang dunia yang ketiga, maka ilmu memiliki keterikatan nilai kepada orang yang menggunakannya (Suriasumantri, 1985, p. 233). Maka, ilmu yang dulu bebas nilai atau tidak memihak, berubah menjadi terikat nilai dan etika dari pengguna ilmu tersebut.

Berdasarkan pandangan di atas, setidaknya terdapat empat alasan perlunya etika pada zaman ini, yaitu: 1) Individu hidup dalam masyarakat yang semakin pluralistik, termasuk di dalamnya di bidang moralitas, 2) Pada saat ini individu berada dalam pusaran transformasi masyarakat yang berlangsung sangat cepat. Gelombang modernisasi membawa perubahan yang mengenai semua segi kehidupan, 3) Bahwa proses perubahan sosial, budaya dan moral yang terjadi ini sering dipergunakan oleh pihak-pihak yang tidak bertanggungjawab untuk memancing dalam air keruh, 4) Etika juga diperlukan oleh kaum agamawan (Suseno, 1993).

\section{DISKUSI}

Filsafat moral atau bisa disebut etika, dalam perkembangannya menjadi kajian yang tidak bisa dilepaskan dari kajian dan penerapan setiap ilmu. Keterkaitan antara etika dalam filsafat ilmu dengan disiplin ilmu dalam hal ini yaitu ilmu bimbingan dan konseling tidak lepas dari proses perkembangan dalam berpikir logis dan filsafati. Plato, Socrates, dan Aristoteles menginginkan bahwa melalui pesan dialog dan percakapan merupakan pelatihan yang baik dalam pencarian kebenaran. Kegiatan logika tersebut dikenal dengan dialektika (Wegmann, 2013, p. 13).

\section{Keterkaitan Etika dalam Bimbingan dan Konseling sebagai Disiplin IImu}

Proses dialektika oleh para ahli diinterpretasikan menjadi suatu bentuk teori tersendiri dalam khazanah keilmuan masing-masing disiplin. Pendekatan 
interaksi individu dalam keilmuan banyak dipakaikan dalam ilmu pengobatan, seperti halnya psikologi dan aplikasinya dalam psikoterapi dan konseling (Wegmann, 2013, p. 13). Psikiater, psikolog, psikoterapi, pekerja sosial dan konselor telah mengambil banyak prinsip-prinsip dasar dari filsafat dan mengaplikasikannya ke dalam kontek modern dalam bentuk konseling dan teori psikologis (Achenbach, 1984; Wegmann, 2013, p. 13). Hal ini dikarenakan konseling seperti halnya psikoterapi menggunakan pendekatan terapeutik dialektika konselor dan konseli (Brammer, 1982).

Inovasi yang dikembangkan oleh teori konseling lebih kepada faktor agama, pengalaman hidup, keluarga, dan budaya. Wolpe, Ellis, Skinner, Rogers, dan Freud merupakan contoh para ahli teori psikologi dan konseling yang mendasari pekerjaan keilmuannya melalui uji dari pengalaman klinis dan proses terapeutiknya melalui pendekatan fondasi filsafat hidupnya masing-masing peneliti (Wegmann, 2013, p. 13). Hal ini menggambarkan keilmuan konseling didasarkan dari etika dan nilai pengalaman individu tersebut dalam mencari kebenaran, dan proses terapeutik yang dilakukan tidak lain proses dialektika yang diterapkan selama ini oleh filosof masa dahulu.

Melalui proses berpikir dialektika, individu yang mempelajari konseling mampu untuk mengembangkan pemahaman mereka sendiri mengenai nilai etika yang konflik dalam diri konseli bisa disetting ulang sesuai dengan kebutuhan dan permintaan. Berpikir dialektika mengenal keberperanan konsep pelengkap yang tidak akan ada tanpa yang lain dipahami secara menyeluruh, karena antara satu konsep variabel dengan yang lain merupakan fenomena yang perlu di integrasikan untuk melakukan pemahaman (Sung \& Hanna, 1996). Proses filsafat moral atau etika dalam konseling sebagai ilmu adalah membentuk individu manusia agar melakukan komunikasi dan interaksi sosial dengan konselor untuk mengungkapkan konflik internal yang saling interaksi dengan dunia luar, sehingga membentuk suatu konsep yang bisa dipahami oleh konseli dengan informasi yang terjadi melalui dialog konselor dengan konseli. Melalui pendekatan filsafat etika dialektika, konselor diperkuat untuk bisa menganalisis dan membantu pembentukkan pribadi konseli (Sung \& Hanna, 1996).

Pendekatan yang dilakukan tergantung target dari masing-masing pendekatan teori yang tokoh psikologi susun, pendekatan ini adalah tujuan untuk membentuk etika yang perlu dibentuk untuk konseli. Seperti halnya pandangan Rogers (1962) mengenai manusia bahwa individu itu unik, dan memiliki kemampuan untuk mengembangkan diri dalam lingkungan yang mengalami perbedaan sosial dan budaya. Dengan perbedaan tersebut adanya kebutuhan individu untuk memperoleh pengakuan positif (positive regard) mengenai dirinya dari individu yang lain. 
Persepsi pengakuan positif dari lingkungan terhadap dirinya memiliki pengaruh langsung terhadap self regard (pengakuan terhadap dirinya sendiri), jika orang tua, saudara, teman dan guru memberikan pengakuan positif dan dia mengakui dirinya positif maka akan memunculkan self worth (harga/nilai mengenai dirinya). Kebutuhan akan pengakuan positif, dan pengakuan diri merupakan esensi dari penghargaan diri sendiri yang individu perlu memiliki kondisi tersebut (Sharf, 2012, p. 212). Untuk mengembangkan kepribadian yang bernilai dan diakui, maka perlu dikembangkan pengalaman condition of worth (kondisi yang individu memiliki nilai positif) dalam lingkungan, yang merupakan proses mengevaluasi pengalaman sendiri berdasarkan pada keyakinan akan diri dan interaksi dengan dunia luar. Individu harus percaya akan pengalaman sendiri dan menerima nilai atau keyakinan dari yang lain akan dirinya, maka hal ini akan melahirkan kondisi positive regard (Sharf, 2012, p. 213).

Begitu juga halnya pendekatan konseling yang dilakukan oleh Albert Ellis dengan Rational Emotive Behavior Therapy (REBT), didasarkan oleh pola pikir etika yang didasari oleh kemampuan filosofis seseorang sangat dekat dengan kemampuan rasional individu dalam berperilaku dan menggambarkan dirinya secara sosial. Kondisi psikologis merupakan kondisi yang paling rapuh dalam pribadi manusia yaitu kognitif, behavioral, dan emosi. Secara praktis, Ellis menekankan pendekatannya kepada penanganan keyakinan yang tidak rasional (irrational belief), dan merusak kehidupan individu (Sharf, 2012, p. 336). Proses terapeutik Ellis lebih melakukan self healing terhadap konseli melalui proses teknik komunikatif dialektika konfrontasi terhadap kondisi konseli.

Penjelasan di atas meneguhkan keterkaitan penerapan filsafat moral (etika) dalam konseling sebagai disiplin ilmu praktis, merupakan dalam hal bentuk proses terapeutik yang dilaksanakan sesuai dari dasar teori konseling yang dikembangkan berdasarkan pemahaman mengenai hakikat manusia itu sendiri. Setiap pendekatan, akan berbeda memandang manusia tergantung bagaimana cara pandang teori tersebut terhadap manusia seharusnya, dan bagaimana melakukan interaksi dialektika dengan manusia tersebut tergantung kasus dan kecenderungan manusia tersebut (nilai etika yang ada dalam diri konseli tersebut).

\section{Dimensi Etika dalam Bimbingan dan Konseling}

Sebagai disiplin ilmu yang mandiri dan praktik, konseling memiliki dimensi etika dan nilai yang dijunjung tinggi oleh setiap pelaku konseling atau bisa disebut dengan ahli ilmu psikologi dan konseling. Dimensi etika dalam konseling dibagi menjadi dua: 1) dimensi etika dalam hubungan konseling dalam proses terapeutik yaitu antara konselor dengan klien/konseli; 2) dimensi etika dari karakter konselor konselor/psikoterapis (Brammer, 1982, p. 144). 


\section{Proses Hubungan Konseling}

1) Unik-Umum: Dimensi etika unik merupakan pemahaman konselor tentang kepribadian dan faktor perilaku karakter konseli memiliki perbedaan meskipun permasalahan konseli memiliki kesamaan. Dalam perspektif ini, setiap masalah adalah umum akan tetapi karakter individu yang unik membuat kondisi masalah tersebut menjadi berbeda dalam skala pengaruh dan edek terhadap kehidupan konseli. Oleh karena itu, konselor tertantang dalam memahami perbedaan individu konseli dalam hal karakter dan kecenderungan psikologisnya.

2) Objektif-Subjektif: Dimensi etika hubungan konselor dengan konseli dilihat dari objektivitas dan subjektivitas harus seimbang (Oppenheimer, 1954) keseimbangan ini berkaitan dengan tingkat intensitas hubungan emosional dan kecenderungan relatif elemen intelektual dan emosional. Hubungan objektif merupakan relasi yang menekankan pada kognitif, keilmuan dan hubungan intelektual. Sedangkan hubungan subjektif menghadirkan keterlibatkan emosional/perasaan dalam bentuk kehangatan dan kedekatan. Dalam etika konseling, harus seimbang antara keobjektifan konselor kepada masalah yang dibahas dengan bagaimana membangun kedekatan atau subjektivitas dengan konseli, sehingga konseli mau menceritakan permasalahan yang dirasakan.

3) Kognitif-Afektif: Dimensi ini menjelaskan bahwa hubungan kognitif merupakan elemen yang berkaitan kemampuan intelektualitas atau pengetahuan konselor dalam hal membagi informasi, memberikan saran dan arahan dengan dasar ilmu dan filosofis. Pada dimensi ini merupakan tahap pembinaan dalam konseling. Keseimbangan antara kognitif dan afektif ini bermaksud dalam hal etika konselor dalam hubungan konseling, tahu kapan memperkuat konseli dari segi pengetahuan maupun dari segi memperkuat secara emosional/afektif. Pada fase ini terjadi dialektika antar konselor dan konseli.

4) Ambiguitas-Clarity: Dimensi etika ambiguitas merupakan hubungan untuk mengajak konseli meragukan kondisi peribadinya dalam hubungan sehingga membangun etika hubungan yang baru dengan konselor, tetapi jika terlalu mendalam etika ambiguitas memunculkan kebingungan bagi konseli. Tujuan membangun hubungan ambiguitas tersebut memberikan kesempatan pada konseli memproyeksikan kondisi perasaannya dalam konseling, konselor tetap menjaga ambiguitas untuk mencapai kejelasan (clarity) dari proses konseling, agar konseling menemukan masalah yang perlu diselesaikan.

5) Responsibilitas-Akuntabilitas: Dimensi tanggung jawab merupakan dimensi etika dimana konselor menerima konseli dalam hubungan konseling, maka konselor telah bertanggung jawab dengan kondisi konseli tersebut. Pada 
proses konseling, konselor memiliki etika hubungan tentang kondisi konseli sebelum dan sesudah konseling, maupun di luar proses konseling. Data konseli, dan kondisi konseli kedepannya dalam hubungan etika profesi adalah tanggung jawab konselor (Brammer, 1982, p. 148).

\section{Karakter Konselor}

1) Keseimbangan Teknis Pribadi: Etika karakter konselor ini merupakan kekuatan yang perlu ada dalam diri konselor, yaitu kekuatan skil interpersonal dan intra personal serta kualifikasi teknis sebagai ahli konseling/psikoterapis.

2) Kompetensi Intelektual: Kompetensi ini merupakan kemampuan dan kecerdasarn yang dimiliki konselor sebagai pribadi yang membantu konseli. Kompetensi ini melingkupi pengalaman, ilmu pengetahuan dan kekuatan dalam kayakinan diri serta kemampuan berpikir logis filsafati.

3) Spontanitas: Etika spontanitas dalam pribadi konselor adalah setiap perilaku dan sikap konselor tidak ada yang dimodifikasi atau dikamuflasekan melainkan murni spontan dalam ekspresi wajah, senyuman, bahasa yang lembut, dan tegas, serta sikap profesional yang spontan muncul dalam diri konselor.

4) Penerimaan dan Peduli: Kondisi pribadi konselor harus memiliki etika yang menerima konseli "apa adanya dan ada apanya". Konselor memiliki kecenderungan peduli kepada konseli. Hal ini disebabkan kondisi konseli yang memiliki persoalan, menginginkan individu diluar dirinya memahami dirinya dan mau menerimanya. Oleh karena itu dimensi etika karakter konselor harus memiliki penerimaan dan kepedulian terhadap konseli.

5) Memahami dan Empati: Kemampuan etika memahami dan empati sangat dibutuhkan dalam hubungan konseling. Merupakan perasaan reaksi yang merupakan bagian konselor yang bisa membuat konseli merasakan dipahami, diterima, dam merasa lingkungan diluar dirinya mengempati kondisinya. Hal ini dilakukan agar konseli merasa nyaman dan mau menceritakan masalahnya pada konselor. Sehingga karakter etika konselor dalam memahami dan empati sangat diperlukan oleh konseli.

6) Hangat dan Interaksi Positif: Karakter hangat dan interaktif positif merupakan dimensi etika karakter yang mendukung kepercayaan dan kenyamanan konseli dalam proses konseling. Konselor harus mememiliki sikap, perilaku dan ekspresi wajah yang hangat dalam berhadapan dengan konseli.

7) Kongruen dan Transparansi: karakter etika konselor dalam hal kongruen merupakan etika kekonsistensian konselor dalam konseling dan transparansi dalam hal data, aturan, etika dan tujuan konseling. Sejak awal proses konseling, etika konselor adalah membangun kontrak dan struktur konseling 
terlebih dahulu, sehingga dalam proses konseling konselor yang kongruen dan transparansi akan mendapatkan kepercayaan dari konseli. Konseli diharapkan dapat ikut dengan konsep transparansi tersebut dalam menceritakan masalahnya pada konselor.

8) Fleksibel: Karakter etika fleksibel sangat dibutuhkan dalam proses terapeutik konseling dan psikoterapi, hal ini dibutuhkan dalam hal meningkatkan keampuhan proses dan efek konsseling. Dalam hal ini fleksibilitas konselor dalam sikap, tindakan, perilaku dan bahasa dalam menggunakan teknik dan kemampuan intelektual dan afektif terhadap konselinya.

\section{Pertimbangan Etika dalam Bimbingan dan Konseling}

Berdasarkan penjelasan sebelumnya, bahwa bimbingan dan konseling sebagai disiplin ilmu yang merupakan cabang dari rumpun ilmu pendidikan yang dipadankan dengan psikologi, memiliki dimensi filsafat moral (etika) dalam proses ilmu pengetahuan, pelaksanaan ilmu tersebut baik bagi pelaku keilmuan tersebut maupun dalam implementasinya bagi konseli. Dasar filsafat moral atau etika yang dilaksanakan oleh ilmu konseling tidak pernah lepas dari proses berpikir logika filsafati dan proses komunikasi dialektika dari tokoh Yunani pada masa lalu. Hal tersebut yang diadaptasi oleh para ahli konseling dan psikoterapi untuk melakukan proses pelaksanaan dan implementasi keilmuan psikologi dalam proses konseling dan terapi dalam proses terapeutik.

Nilai etika dikembangkan lebih jauh dalam bentuk perumusan aturan kode etik agar keilmuan bimbingan dan konseling berjalan aplikatif, juga dapat terlegalisasi oleh pemerintah. Selain kode etik yang berlaku global, dasar kode etik bimbingan dan konseling di Indonesia tidak lepas dari nilai Pancasila dan norma-norma yang berlaku dalam masyarakat Indonesia. Tuntutan profesi mengacu pada kebutuhan dan kebahagiaan konseli sesuai dengan norma yang berlaku, maka kode etik dapat dirumuskan sebagai berikut:

1) Memiliki wawasan, Pengetahuan, Keterampilan, Nilai dan Sikap; hal ini meliputi konselor memiliki wawasan dan pemahaman sebaik-baiknya mengerti dan menyadari kelemahan dan kelebihan diri serta melakukan perubahan diri dan menyingkirkan prasangka, memiliki pengathuan tidak hanya pada diri sendiri tetapi juga pada orang lain dari segi keilmuan dan memiliki nilai sikap yang sederhana, sabar, dapat dipercaya (amanah), disiplin, dan tertib, serta memiiki kewibawaan sebagai konselor.

2) Memiliki pengakuan dan wewenang yang diatur oleh pemerintah dengan bukti legalitas sebagai tenaga konselor dan ahli konseling.

3) Memiliki kemampuan dalam penyimpanan dan penggunaan informasi konseli, mampu menjaga kerahasiaan data dan informasi tentang konseli, sehingga jika tetap disampaikan juga informasi tersebut harus persetujuan konseli, serta 
bisa menyelenggarakan instrumentasi pengungkaapan data konseli sesuai dengan mtode yang terukur dan terpercaya.

4) Mampu membangun hubungan konseling yang baik dan benar sesuai dengan ketentuan dan tahap konseling yang telah baku, dan mampu membangun hubungan baru dengan konseli tanpa perilaku yang dibuat-buat melainkan secara alamiah.

5) Mampu berinteraksi dan menjalin komunikasi dengan rekan sejawat sebagai bentuk diskusi keilmuan dan sebidang untuk kemajuan kondisi konseli dan kemajuan dan pengembangan diri konselor sendiri. Secara profesional konselor harus bisa melaksanakan alih tangan kasus ketika tidak mampu membantu konseli kepada konselor yang lebih mampu dan lebih kompeten.

Dalam pandangan John McLeod (2010), terdapat empat etika yang penting dalam konseling, yaitu:

Pertama, Profesional Responsibility. Selama proses konseling berlangsung, seorang konselor harus bertanggung jawab terhadap konselinya dan dirinya sendiri. Ada beberapa hal yang perlu diperhatikan: 1) Responding fully, artinya konselor harus bertanggung jawab untuk memberi perhatian penuh terhadap konseli selama proses konseling; 2) Terminating appropriately, dapat melakukan terminasi (menghentikan proses konseling) secara tepat; 3) Evaluating the relationship, yakni relasi antara konselor dan konseli haruslah relasi yang terapeutik namun tidak menghilangkan yang personal; 4) Counselor's responsibility to themselves, dimana konselor harus dapat membangun kehidupannya sendiri secara sehat, sehingga ia sehat secara spiritual, emosional dan fisikal.

Kedua, Confidentiality. Konselor harus menjaga kerahasiaan konseli. Ada beberapa hal yang perlu penjelasan dalam etika ini, yaitu yang dinamakan previleged communication. Artinya konselor secara hukum tidak dapat dipaksa untuk membuka percakapannya dengan konseli, namun untuk kasuskasus yang dibawa ke pengadilan, hal seperti ini bisa bertentangan aturan dari etika itu sendiri. Dengan demikian tidak ada kerahasiaan yang absolut.

Ketiga, Conveying Relevant Information to the Person in Counseling. Maksudnya konseli berhak mendapatkan informasi mengenai proses konseling yang berjalan. Informasi tersebut adalah: 1) Counselor qualifications: konselor harus memberikan informasi tentang kualifikasi atau keahlian yang dimiliki 2) Counseling consequences: konselor harus memberikan informasi tentang hasil yang dicapai dalam konseling dan efek samping dari konseling; 3) Time involved in counseling: konselor harus memberikan informasi kepada konseli berapa lama proses konseling yang nanti dijalani oleh konseli. Konselor harus bisa memprediksikan setiap kasus membutuhkan berapa kali pertemuan. Misalnya 
konselor dan konseli bertemu seminggu sekali selama 15 kali, kemudian sebulan sekali, dan setahun sekali; 4) Alternative to counseling: konselor harus memberikan informasi kepada konseli bahwa konseling bukanlah satu-satunya jalan untuk sembuh, ada faktor lain yang berperan dalam penyembuhan, misalnya: motivasi konseli, natur dari masalah, dan sebagainya.

Keempat, the Counselor Influence. Konselor mempunyai pengaruh yang besar dalam relasi konseling, sehingga ada beberapa hal yang perlu konselor waspadai yang akan mempengaruhi proses konseling dan mengurangi efektifitas konseling. Hal-hal tersebut adalah: 1) The counselor needs: kebutuhankebutuhan pribadi seorang konselor perlu dikenali dan diwaspadai supaya tidak mengganggu efektifitas konseling; 2) Authority: pengalaman konselor dengan figur otoritas juga perlu diwaspadai karena akan mempengaruhi proses konseling jika konselinya juga figur otoritas; 3) Sexuality: konselor yang mempunyai masalah seksualitas yang belum terselesaikan akan transference; 4) The counselor's moral and religius values: nilai moral dan religius yang dimiliki konselor akan mempengaruhi persepsi konselor terhadap konseli yang bertentangan dengan nilai-nilai yang dipegang.

\section{SIMPULAN}

Bimbingan dan konseling sebagai ilmu terapan dengan multidisipliner ilmu, memiliki peranan penting dalam pendidikan untuk membentuk lingkungan dan kondisi konseli /klien menjadi lebih baik dengan menerapkan dimensi etika yang menjadi dasar dari filosofis moral untuk ilmu bimbingan dan konseling. Dimensi etika dalam konseling tidak lepas dari dimensi filsafat moral dan etika yang selama ini dipraktikkan pada masa lampau, dengan tujuan untuk membantu etika dan moral konseli agar memiliki etika diri dan moral diri yang sesuai dengan lingkungan sosial dan sistem sosialnya.

Konselor haruslah menjunjung tinggi nilai etika dalam melaksanakan keahlian konselingnya dan mempribadikan dimensi etika konseling tersebut dalam praktik pelayanan konseling. Konselor harus memahami dan memiliki wawasan yang luas dalam ilmu dan pengetahuan serta pengalaman terkait disiplin psikologi, sosiologi, antropologi, pendidikan dan agama.

\section{REFERENSI}

Achenbach, G. B. (1984). Philosophy, philosophical practice, and psychotherapy. In R. Lahav \& M. Tillman (Eds.), Essays on philosophical counseling (1995). New York: University Press of America. 
Brammer, L., \& Shostrom, E. (1982). Therapeutic psychology; Fundamental of counseling and psychotherapy. Fourth edition. New Jersey: Prentice Hall.

Burhanuddin. A. (2013). Etika keilmuwan. Retrieved May 20, 2017, from website: https://afidburhanuddin.files.wordpress.com/2012/05/etikakeilmuan_2013_ 1.pdf.

Craig, E. (Ed.). (1998). Routledge encyclopedia of philosophy: Vol. 1. London: Routledge.

McLeod, J. (2010). Pengantar konseling teori dan studi kasus (Trans.). Jakarta: Kencana Prenada Media Group. (An introduction to counselling. Original work published 1993).

Naisaban, L. (2004). Para psikolog terkemuka dunia: Riwayat hidup, pokok pikiran, dan karya. Jakarta: Grasindo.

Rogers, C. R. (1962). The interpersonal relationship. Harvard Educational Review, 32(4), 416-429.

Oppenheimer, O. (1954). Some counseling theory: objectivity and subjectivity. Journal of Counseling Psychology, 1(3), 184-187.

12 Sharf, S. R. (2012). Theories of psychotherapy and counseling. 5th Edition. Belmont, USA: Brooks/Cole.

Sung, J., \& Hanna, S. (1996). Factors related to risk tolerance. Journal of Financial Counseling and Planning, 7, 11-19.

Suriasumantri, J. S. (1985). Filsafat ilmu: Sebuah pengantar populer. Jakarta: Pustaka Sinar Harapan.

Suriasumantri, J. S. (2009). IImu dalam perspektif. Jakarta: Yayasan Obor Indonesia.

Suseno, F. M. (1987). Etika dasar. Yogyakarta: Kanisius.

Sya'roni, M. (2014). Etika keilmuan: Sebuah kajian filsafat ilmu. Jurnal THEOLOGIA, 25(1), 245-270.

Wegmann, M. (2013). Philosophy and counseling: A case study. University of New Orleans.

Wilujeng, S. R. (2013). Filsafat, etika dan ilmu: Upaya memahami hakikat ilmu dalam konteks keindonesiaan. HUMANIKA, 17(1), 79-90. 